\title{
Anti-cyclic citrullinated peptide antibody titer predicts time to rheumatoid arthritis onset in patients with undifferentiated arthritis: results from a 2-year prospective study
}

\author{
Nicola Bizzaro ${ }^{1 * \dagger}$, Elena Bartoloni ${ }^{2 \dagger}$, Gabriella Morozzi ${ }^{3}$, Stefania Manganelli ${ }^{3}$, Valeria Riccieri ${ }^{4}$, Paola Sabatini ${ }^{5}$, \\ Matteo Filippini ${ }^{6}$, Marilina Tampoia ${ }^{7}$, Antonella Afeltra ${ }^{8}$, Giandomenico Sebastiani ${ }^{9}$, Claudia Alpini ${ }^{10}$, Vittorio Bini ${ }^{11}$, \\ Onelia Bistoni ${ }^{2}$, Alessia Alunno ${ }^{2}$ and Roberto Gerli ${ }^{2}$, for \\ the Forum Interdisciplinare per la Ricerca nelle Malattie Autoimmuni (FIRMA Group)
}

\begin{abstract}
Introduction: The diagnostic, predictive and prognostic role of anti-cyclic citrullinated peptide (CCP) antibodies in rheumatoid arthritis (RA) patients is widely accepted. Moreover, detection of these antibodies in subjects presenting with undifferentiated arthritis (UA) is associated with a significant risk to develop the disease. On the other hand, clinical and prognostic significance of evaluating anti-CCP levels in subjects with inflammatory arthritis at disease onset has not been fully clarified. The goal of this prospective study is to analyze the value and prognostic significance of anti-CCP titer quantification in UA subjects.
\end{abstract}

Methods: Serial anti-CCP assays were measured in 192 consecutive patients presenting with UA lasting less than 12 weeks. Clinical and serological data and arthritis outcome were evaluated every 6 months until two years of follow-up.

Results: Anti-CCP positivity, at both low and high titer, and arthritis of hand joints significantly predicted RA at two years, risk increasing in subjects with high anti-CCP titers at baseline. Moreover, time to RA diagnosis was shorter in patients with high anti-CCP2 titers at enrollment with respect to those with low antibody concentration.

Conclusions: Presence of anti-CCP antibodies, at both low and high concentration, is significantly associated with RA development in subjects with recent onset UA. However, time interval from the onset of the first symptoms to the fulfilment of the classification criteria appears to be directly related to the initial anti-CCP level.

\section{Introduction}

In recent years, the broad availability of specific serological markers deeply changed the diagnostic approach to rheumatoid arthritis (RA), a chronic inflammatory disease associated with a progressive and often disabling course if not promptly recognized and effectively treated. In this setting, anti-citrullinated peptide antibodies (ACPA), commonly detected by means of the second

\footnotetext{
* Correspondence: nicola.bizzaro@ass3.sanita.fvg.it

† Contributed equally

'Laboratorio di Patologia Clinica, Ospedale San Antonio, 33028 Tolmezzo, Italy
}

Full list of author information is available at the end of the article generation anti-cyclic citrullinated peptide test (antiCCP2), represent a peculiar feature of RA patients [1]. To meet the need of improved diagnostic and prognostic tests, the progressive evolution of the analytical methods for ACPA detection, as measured by quantitative immunometric assays, have led to a very high level of diagnostic accuracy with a specificity of $95 \%$ to $97 \%$ and a sensitivity of $67 \%$ to $80 \%$ [2,3]. The sensitivity values are likely the highest obtainable in relation to the close link existing between the production of ACPA and genetic constitution [4]. At the moment, the anti-CCP2 antibody test yields higher specificity and comparable or even higher sensitivity with respect to rheumatoid factor
C Biomed Central

(c) 2013 Bizzaro et al.; licensee BioMed Central Ltd. This is an open access article distributed under the terms of the Creative Commons Attribution License (http://creativecommons.org/licenses/by/2.0), which permits unrestricted use, distribution, and reproduction in any medium, provided the original work is properly cited. 
(RF) or other ACPA, including the recently discovered anti-mutated citrullinated vimentin antibodies [5].

In established disease, it is has been widely demonstrated that the presence, in particular at high levels, of anti-CCP is associated with more severe clinical outcomes, higher disease activity and worse radiographic progression [6-9]. Moreover, retrospective studies have assessed their predictive value demonstrating that anti-CCP can be detected in the serum of subjects later developing RA up to fourteen years before the first clinical symptoms, with titer significantly increasing closer to disease onset $[10,11]$. Similar findings have been obtained in studies involving patients with early disease, thus confirming the clinical utility of anti-CCP as a diagnostic and prognostic tool in subjects presenting with RA lasting less than one or two years $[1,5]$. As a consequence, the new 2010 RA Classification Criteria, which have been updated in order to diagnose $\mathrm{RA}$ in an earlier phase, included detection of ACPA as a key item for diagnosing the disease [12].

Finally, anti-CCP antibodies may have an important role in the diagnostic algorithm of subjects presenting with undifferentiated arthritis (UA). Indeed, UA accounts for $30 \%$ to $50 \%$ of patients presenting to the rheumatologist and has a variable natural course. In particular, progression to RA has been reported in only one-third of patients after 1 year and in $40 \%$ after 3 years [13]. In order to minimize the risk of diagnostic pitfalls and subsequent underor over-treatment, clinical, serologic and instrumental markers have been employed to estimate the likelihood of progression to RA in these subjects. Among these, serum anti-CCP positivity at baseline has been demonstrated to possess very high predictive and prognostic accuracy in comparison to other markers [14]. Interestingly, a recent study showed that early introduction of methotrexate therapy in UA patients with circulating anti-CCP delays evolution to RA, and prevents joint damage [15].

Although some questions remain unanswered regarding the significance of anti-CCP detection in patients with $\mathrm{UA}$, quantification of anti-CCP serum level is now considered a key investigational issue and the important role played by antibody level on disease outcome has been underlined by the different scores attributed to antibody serum levels in the new classification criteria for RA [12]. Indeed, in early RA lasting less than 1 year, it has been demonstrated that anti-CCP positivity at any time is associated with higher risk of radiographic damage at baseline [16]. Interestingly, increase in antibody titer during the first 3 years of follow up was shown to significantly correlate with radiographic progression after 5 years [16]. However, in a similar patient population, anti-CCP serum levels did not seem to correlate with disease activity and severity, thereby suggesting that anti-CCP-positive patients with early RA have higher disease activity and severity independent of antibody titer [17].
On the other hand, studies analyzing the value and prognostic significance of anti-CCP titer quantification in UA patients at disease onset are very few, and results quite contradictory, mainly because of different study design and population enrollment criteria. In UA patients with evidence of circulating anti-CCP at disease onset, it has been demonstrated that antibody status appears to remain substantially stable during a disease course of up to 5 years of follow up, with a rate of seroconversion ranging from $1 \%$ to $9 \%$ [18-21]. Thus, the utility of anti-CCP retesting during the disease course in patients presenting with inflammatory arthritis is actually questionable and not recommended. On the other hand, the clinical value of anti-CCP levels at disease onset and influence of titer changes over time on disease outcome have not been fully clarified.

Therefore, the aim of this multicenter prospective study was to analyze the value and prognostic significance of anti-CCP titer quantification and monitoring in a cohort of patients presenting with UA.

\section{Material and methods \\ Study subjects}

Consecutive patients with UA were recruited at nine rheumatology units belonging to the Forum Interdisciplinare per la Ricerca nelle Malattie Autoimmuni (FIRMA group), an Italian association of hospital and university experts in the field of autoimmune rheumatic diseases. The cohort included patients aged more than 18 years presenting with either mono-, oligo- or polyarticular arthritis lasting less than 12 weeks, and not meeting the 1987 American College of Rheumatology (ACR) classification criteria for RA, nor fulfilling any of the existing classification criteria for other inflammatory rheumatic disease. Evidence of radiographic joint damage or rheumatoid nodules represented exclusion criteria. Only nonsteroidal anti-inflammatory drugs (NSAIDs) or Cox-2 selective inhibitors (Coxibs) and/or low-dose of corticosteroids (CS) (prednisone $<15 \mathrm{mg}$ a day or equivalent) were allowed in the period from symptom onset to the time of enrollment. Patient recruitment began in March 2007 and was stopped in May 2009 after the inclusion of 206 patients. Subjects were assessed by a trained rheumatologist at baseline and every 6 months thereafter. Follow-up was continued until the last enrolled patient completed two years of follow-up. Demographic data were assessed at baseline and clinical and serological data were recorded at each visit. Diagnosis of RA or of any other rheumatic or non-rheumatic disorder was performed by the referring rheumatologists.

Each enrolled patient gave written consent prior to being included in the study. Patient identity was not disclosed and the data were anonymously used in accordance with the latest version of the Helsinki Declaration of 
human research ethics. Collection of patient samples was carried out according to the University-Hospital of Udine Ethic Committee regulations.

\section{Methods}

Serum samples were collected at baseline and every 6 months. Overall, therefore, four serum samples were obtained from each patient. ACPAs were measured by the routine commercial method used in each participating center, according to manufacturer's instructions. They were determined by CCP2-based assays, manufactured by Phadia (Uppsala, Sweden) (three centers), AxisShield (Dundee, UK) (three centers), Eurodiagnostica (Nijmegen, The Netherlands) (two centers) and Inova (San Diego, CA, USA) (one center). To harmonize and compare results obtained by the different assays, antiCCP2 levels were expressed as a ratio, dividing the observed absolute antibody amount by the cutoff value of each commercial kit. Serum levels less than, or more than three times the cutoff were considered low and high, respectively.

IgM RF, erythrocyte sedimentation rate (ESR) and Creactive protein (CRP) levels were locally determined by each participating center. Since the nine centers employed different analytical methods with different cutoffs, RF, ESR and CRP values were also converted to ratios, as described for anti-CCP2 values.

\section{Statistical analysis}

Student's $t$-test and the Mann-Whitney test were used to compare normally and non-normally distributed continuous variables respectively (deviation from the Gaussian distribution were checked using the Shapiro-Wilk test). The chi squared $\left(\mathrm{X}^{2}\right)$ test with Yate's continuity correction was used to analyze categorical variables. To estimate the survival function from the time of arthritis onset to the time of RA diagnosis, the Kaplan-Meier method was used. The risk of developing RA according to CRP, RF, anti-CCP2, and arthritis of the hand joints, was estimated by the Cox proportional hazard model, first adding one variable at time (un-adjusted hazard ratio, HR), and then all variables together (adjusted HR).

Biochemical variables were evaluated as categorical variables and divided into three levels as suggested by the ACR/European League Against Rheumatism (EULAR) criteria. Two-tailed $P$-values lower than 0.05 were considered statistically significant. Calculations were performed with Stata 8.2 software (Stata Corporation, College Station, Texas, USA).

\section{Results}

Among the 206 enrolled patients, 192 (93.2\%) completed the study and 14 were lost during follow up, mainly because they moved to another location. Table 1 shows the baseline characteristics of the patient cohort. It includes 147 women and 45 men with a mean age of $52 \pm$ SD, 16 years. Most patients had polyarthritis $(60.9 \%)$ and only $9.4 \%$ of them presented with monoarthritis at onset. In about two-thirds of the cases, joint synovitis was localized at the hands.

A consistent number of patients $(n=79,41.4 \%)$ were positive for RF (mean ratio: $3.8 \pm$ SD 8.2 ) and/or antiCCP2 ( $n=80,41.7 \%$; mean ratio $7.8 \pm$ SD 17$)$ at baseline. Among the RF-positive subjects, $67.1 \%$ displayed high RF titers, while in the group of anti-CCP2-positive subjects, an even higher percentage (83.8\%) displayed high anti-CCP2 levels in the serum. Many patients (45.8\%) were out of therapy, 66 patients $(34.4 \%)$ were taking NSAIDs or Coxibs, while a small number of subjects were taking CS in combination with, or without NSAIDs/Coxibs.

As depicted in Table 2, 72/192 (37.5\%) patients had progressed to RA at 2 years from recruitment: 26 at 6 months, 20 at 12 months and 26 at 24 months. Among those who did not develop RA, a rheumatic disease other than RA (largely psoriatic arthritis and undifferentiated connective tissue disease) was diagnosed in 30 patients (15.6\%). In addition, arthritis was transitory and eventually remitted in 32 patients (16.7\%), while no definite diagnosis was made at 24 months in 58 of them (30.2\%) and a diagnosis of UA was thus maintained.

Table 3 shows the baseline characteristics of the patient cohort who developed RA at the end of the study, compared to the patients who did not. Age, gender and number of involved joints at presentation did not help in distinguishing patients developing RA during follow up, while hand articular involvement was more frequent at baseline in subjects developing RA. Moreover, higher initial levels of CRP but not of ESR, were associated with a higher possibility of developing RA. In addition, the majority of patients with a diagnosis of RA at the end of the study were RF-positive and had much higher titers of RF at presentation than patients who did not develop the disease. However, the percentage of patients with either low or high RF titer at symptom onset in RA and non-RA patients was similar.

Among subjects who developed RA, the majority had anti-CCP2 at presentation (73.6\%), while only $22.5 \%$ of non-RA patients displayed these antibodies $(P<0.0001)$. Interestingly, although the anti-CCP2 mean ratio at baseline in the RA cohort was up to 3.5-fold higher than that observed in the non-RA group $(P<0.0001)$, the percentage of patients with either low or high antiCCP2 titers at enrollment did not differ in the RA and non-RA groups. Furthermore, the presence at recruitment of a single positivity for RF, without evidence for 
Table 1 Baseline demographic, clinical and serological characteristics of the 192 patients with undifferentiated arthritis

\begin{tabular}{|c|c|c|}
\hline Characteristics & Baseline values & Percent patients \\
\hline Age, years, mean $\pm S D$ & $52 \pm 16$ & na \\
\hline Female, $\mathrm{n}$ & 147 & 76.6 \\
\hline Monoarthritis, n & 18 & 9.4 \\
\hline Oligoarthritis, n & 57 & 29.7 \\
\hline Polyarthritis, $n$ & 117 & 60.9 \\
\hline Arthritis of hand joints, $n$ & 126 & 65.6 \\
\hline \multicolumn{3}{|l|}{ CRP } \\
\hline Positive, $n$ & 98 & 51.0 \\
\hline Ratio, median (IR) & $1.1(0.6-4.1)$ & na \\
\hline \multicolumn{3}{|l|}{ ESR } \\
\hline Increased, n & 103 & 53.6 \\
\hline Ratio, median (IR) & $22.5(14-40)$ & na \\
\hline \multicolumn{3}{|l|}{ Rheumatoid factor } \\
\hline Positive & 79 & $(41.4)$ \\
\hline Ratio, median (IR) & $0.7(0.5-3.9)$ & na \\
\hline Low titer on total positive & 26 & $(32.9)$ \\
\hline High titer on total positive & 53 & $(67.1)$ \\
\hline \multicolumn{3}{|l|}{ ACPA } \\
\hline Positive, $n$ & 80 & $(41.7)$ \\
\hline Ratio, median (IR) & $0.5(0.3-7.8)$ & na \\
\hline Low levels on total positive, $n$ & 13 & $(16.2)$ \\
\hline High levels on total positive, $\mathrm{n}$ & 67 & $(83.8)$ \\
\hline \multicolumn{3}{|l|}{ Baseline therapy } \\
\hline None, $\mathrm{n}$ & 88 & $(45.8)$ \\
\hline NSAIDs/Coxibs, n & 66 & $(34.4)$ \\
\hline Corticosteroids, n & 10 & $(5.2)$ \\
\hline
\end{tabular}

$\mathrm{n}$, number of patients; CRP, C-reactive protein; IR, interquartile range; ESR, erythrocyte sedimentation rate; ACPA, anti-citrullinated peptide antibodies; NSAID, nonsteroidal anti-inflammatory drug; Coxib, Cox-2 selective inhibitor; na, not applicable.

anti-CCP2, was not able to discriminate between subjects who would or would not develop RA, while the percentage of anti-CCP2-positive patients was higher in the RA cohort independent of the evidence of

Table 2 Diagnosis at the end of follow up (2 years)

\begin{tabular}{lc}
\hline Diagnosis & Number of patients (\%) \\
\hline Rheumatoid arthritis & $72(37)$ \\
Undifferentiated arthritis & $58(30)$ \\
Remission & $32(17)$ \\
Psoriatic arthritis & $11(6)$ \\
Undifferentiated connective tissue disease & $8(4)$ \\
Fibromyalgia & $4(2)$ \\
Spondiloarthritis & $2(1)$ \\
Viral arthritis (EBV) & $1(0.5)$ \\
Systemic lupus erythematosus & $1(0.5)$ \\
Osteoarthritis & $1(0.5)$ \\
Sarcoidosis & $1(0.5)$ \\
Primary Sjögren's syndrome & $1(0.5)$ \\
Total & $192(100)$ \\
\hline
\end{tabular}

EBV, Epstein-Barr virus.
RF-positivity. It is of note that the percentage of antiCCP2-positive patients and anti-CCP2 titers remained substantially stable during follow up (data not shown).

Finally, the initial treatment with NSAIDs/Coxibs and/ or CS did not appear to influence the subsequent development of arthritis (data not shown).

On univariate regression analysis, inflammatory involvement of the hand joints, high CRP levels, and RF and anti-CCP2 at both low and high titers were predictive of RA development (Table 4). However, on multivariate analysis adjusted for the covariates CRP, RF, anti-CCP2 and arthritis of the hand joints, only arthritis of the hand joints and anti-CCP2, at both low and high titers predicted RA, with a risk of 3.2 for low, and 4.3 for high anti-CCP2 titers at baseline.

As shown in Figure 1, time from presentation to diagnosis of RA was related to anti-CCP2 levels at baseline, since this period was shorter in patients having high anti-CCP2 titers at enrollment with respect to those displaying basal low anti-CCP2 levels. However, the RAfree survival curve in the two groups overlapped at the end of 2-year follow up. 
Table 3 Baseline demographic, clinical and serological characteristics of the 192 patients subdivided according to diagnosis after 24 months

\begin{tabular}{|c|c|c|c|c|c|}
\hline \multirow[t]{2}{*}{ Parameter at onset } & \multicolumn{2}{|c|}{ Patients developing RA } & \multicolumn{2}{|c|}{ Patients not developing RA } & \multirow[t]{2}{*}{$P$} \\
\hline & Number & $\%$ & Number & $\%$ & \\
\hline Patients & 72 & 37.5 & 120 & 62.5 & \\
\hline Age, years, mean $\pm S D$ & $52 \pm 16$ & na & $52 \pm 15$ & na & 0.895 \\
\hline Female & 57 & 79.2 & 90 & 75.0 & 0.628 \\
\hline Monoarthritis & 7 & 9.7 & 11 & 9.2 & 0.999 \\
\hline Oligoarthritis & 16 & 22.2 & 41 & 34.2 & 0.111 \\
\hline Polyarthritis & 49 & 68.1 & 68 & 56.6 & 0.158 \\
\hline Hand joints arthritis & 55 & 76.4 & 71 & 59.2 & 0.023 \\
\hline CRP+ & 41 & 56.9 & 58 & 48.3 & 0.314 \\
\hline CRP ratio, median (IR) & $1.9(0.6-1.9)$ & & $0.9(0.6-2.6)$ & & 0.031 \\
\hline ESR increase & 38 & 52.8 & 65 & 54.2 & 0.970 \\
\hline ESR median (IR) & $24(12.3-53.3)$ & & $22.5(16.0-38)$ & & 0.773 \\
\hline RF+ & 45 & 62.5 & 34 & 28.3 & $<0.0001$ \\
\hline RF ratio, median (IR) & $2.3(0.6-7.8)$ & & $0.6(0.5-1.2)$ & & $<0.0001$ \\
\hline RF low+/total RF+ & 11 & 24.4 & 15 & 44.1 & 0.109 \\
\hline RF high+/total RF+ & 34 & 75.5 & 19 & 55.9 & \\
\hline ACPA+ & 53 & 73.6 & 27 & 22.5 & $<0.0001$ \\
\hline ACPA ratio, median (IR) & $5(0.6-14.3)$ & & $0.5(0.3-0.8)$ & & $<0.0001$ \\
\hline ACPA low+/total+ & 7 & 13.2 & 6 & 22.2 & 0.476 \\
\hline ACPA high+/total+ & 46 & 86.8 & 21 & 77.8 & \\
\hline $\mathrm{RF}+/ \mathrm{ACPA}-$ & 2 & 2.8 & 12 & 10 & 0.115 \\
\hline $\mathrm{RF}-/ \mathrm{ACPA}+$ & 10 & 13.9 & 5 & 4.2 & 0.031 \\
\hline $\mathrm{RF}+/ \mathrm{ACPA}+$ & 43 & 59.7 & 21 & 18.3 & $<0.0001$ \\
\hline RF-/ACPA- & 17 & 23.6 & 81 & 67.5 & $<0.0001$ \\
\hline
\end{tabular}

RA, rheumatoid arthritis; CRP, C-reactive protein; IR, interquartile range; ESR, erythrocyte sedimentation rate; RF, rheumatoid factor; ACPA, anti-citrullinated peptide antibodies; NA, not applicable.

During the study period, patients were treated with anti-inflammatory drugs, or disease modifying anti-rheumatic drugs (DMARDs), but there was no relationship between the change in anti-CCP2 levels and the therapy introduced (data not shown). Moreover, no significant relationship was detected between anti-CCP2 titer and the other parameters, in particular ESR and CRP (data not shown).

\section{Discussion}

In recent years, the generation of serological tests for accurate ACPA detection lead to an impressive improvement in the diagnosis of inflammatory articular disorders. In particular, anti-CCP2 assays are helpful in various clinical settings, such as early diagnosis of RA, diagnosing RF-negative RA and differentiating other RF-positive arthritis, such as hepatitis $C$ virus-related joint involvement $[1,22]$. Moreover, in subjects presenting with UA, evidence of anti-CCP2 positivity at baseline appears to have relevant diagnostic, predictive and prognostic value [16,23-25]. On the other hand, major uncertainty remains about the clinical and prognostic significance of anti-CCP2 titer in UA subjects, in particular in subjects presenting with borderline antibody values. These doubts are further strengthened by the observation that many non-RA sera with low ACPA levels bind equally to citrullinated and non-citrullinated peptides and that low ACPA levels may not discriminate between true and false positive results [26]. Thus, specificity of low-positive samples remains a diagnostic issue.

In the present prospective study recruiting subjects with recent onset UA, 37\% of them developed RA at 2 years, while $30 \%$ maintained persistent UA. The available data in the literature show that the percentage of UA subjects developing RA or persistent arthritis is highly variable, ranging from $7 \%$ to $72 \%$. The wide range of RA diagnoses may be related to different lengths of follow up, which in particular, was shorter in many studies with respect to that of our investigation [27-30]. Indeed, it is conceivable that some UA patients may experience progression to RA after more than 1 year of follow up. In addition, the design of some studies also did not rule out baseline recruitment of subjects fulfilling the ACR 1987 RA classification criteria. The introduction of DMARDs in this group of patients at enrollment may hamper the interpretation and comparison of the data $[21,29,31]$. Finally, the pattern of inflammatory joint involvement, and most importantly, 
Table 4 Risk of developing rheumatoid arthritis: Cox regression univariate and multivariate hazards ratio (HR) analysis

\begin{tabular}{|c|c|c|c|c|}
\hline & $\begin{array}{l}\text { HR }(95 \% \mathrm{Cl}) \\
\text { Unadjusted }\end{array}$ & $P$ & $\begin{array}{l}\text { HR }(95 \% \mathrm{Cl}) \\
\text { Adjusted }\end{array}$ & $P$ \\
\hline \multicolumn{5}{|l|}{ CRP } \\
\hline Negative & 1 & & 1 & \\
\hline Low + & $0.720(0.362,1.434)$ & 0.350 & $0.875(0.423,1.811)$ & 0.719 \\
\hline High+ & $1.737(1.049,2.877)$ & 0.032 & $1.827(0.950,3.514)$ & 0.071 \\
\hline \multicolumn{5}{|l|}{ RF } \\
\hline Negative & 1 & & 1 & \\
\hline Low+ & $2.020(1.001,4.073)$ & 0.050 & $0.791(0.248,2.522)$ & 0.692 \\
\hline High+ & $3.097(1.867,5.137)$ & $<0.001$ & $0.729(0.219,2.431)$ & 0.607 \\
\hline \multicolumn{5}{|l|}{ ACPA } \\
\hline Negative & 1 & & 1 & \\
\hline Low + & $3.360(1.412,7.998)$ & 0.006 & $3.187(1.257,8.077)$ & 0.015 \\
\hline High + & $4.613(2.698,7.887)$ & $<0.001$ & $4.324(2.023,9.245)$ & $<0.001$ \\
\hline Hand joints arthritis & $1.871(1.083,3.232)$ & 0.025 & $2.140(1.128,4.059)$ & 0.020 \\
\hline
\end{tabular}

CRP, C-reactive protein; RF, rheumatoid factor; ACPA, anti-citrullinated peptide antibodies.

the duration of joint symptoms at inclusion ranging from more than four weeks to less than 3 years, produced quite variable differences in results between different studies. In this setting, the very short duration of UA, the exclusion of patients with definite arthritis and the inclusion of all patterns of arthritis, which characterize the enrolled population, may represent a potential strength of this study.
The analysis of clinical and serological characteristics of our UA patients at presentation showed that those developing RA at 2 years more frequently had inflammatory involvement in the hand and higher CRP, RF and anti-CCP2 titers in comparison to non-RA subjects. Although the same items predicted RA on univariate analysis, only patients with hand arthritis and anti-CPP2

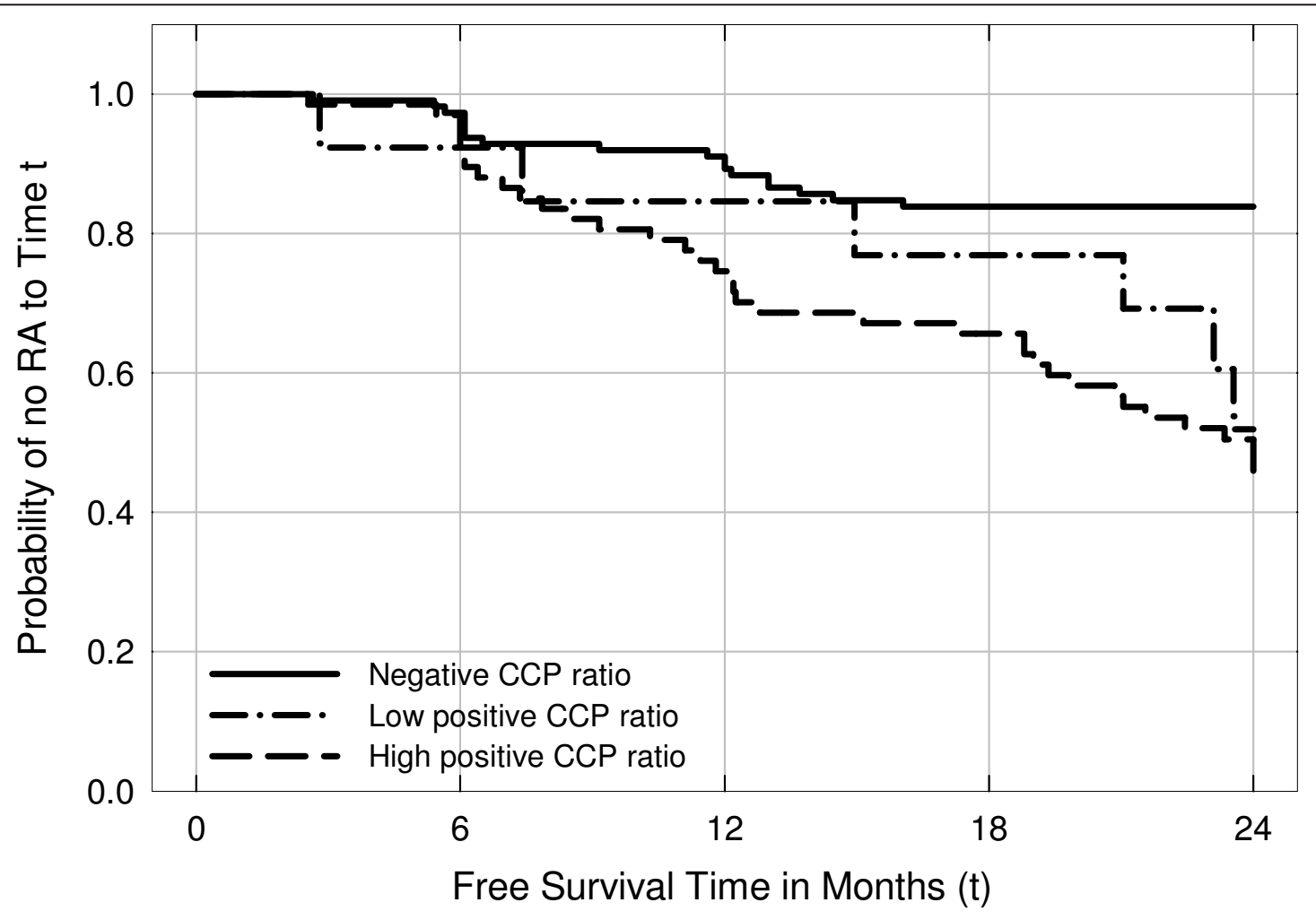

Figure 1 Time to reach rheumatoid arthritis (RA) diagnosis according to anti-cyclic citrullinated peptide 2 (CCP2) levels in 192 patients with undifferentiated arthritis. Data were analyzed by Kaplan-Meier analysis and the log-rank test. 
positivity presented a significantly increased risk of developing RA on multivariate analysis.

The percentage of anti-CCP2-positive UA patients included in the present study was within the range of anti-CCP2 positivity described in UA cohorts in other studies $(14 \%$ to $59 \%)$. In this setting, it is of note that the proportion of anti-CCP2-positive patients at baseline was higher in subjects with RA diagnosis with respect to non-RA subjects, independent of RF positivity, while the percentage of patients with single positivity for RF (antiCCP2-negative) was similar in the RA and non-RA groups. Moreover, CRP and ESR levels do not appear to have an effect on risk of progression to RA. Taken together, these observations confirm the key prognostic role of anti-CCP2 for RA diagnosis, rather than RF and inflammatory parameters.

In agreement with previous studies [21,32], we did not observe any effect of age and gender on anti-CCP2 levels in the different patient groups. On the other hand, the genetic background may exert a relevant adjunctive role in the risk of disease development. Interestingly in fact, anti-CCP2-positive UA patients who will develop RA display reactivity against a significant larger number of citrullinated epitopes, namely vimentin, fibrinogen and $\alpha$-enolase, with respect to anti-CCP2-positive patients not evolving toward RA at one year of follow up, thus postulating a very distinct immunological reactivity profile at disease onset [33].

Recent prospective studies showed that higher baseline anti-CCP titer is significantly correlated to increased likelihood of persistent arthritis or RA development in cohorts of subjects presenting with UA $[21,27,29,30]$ (Table 5). Moreover, the likelihood of persistent arthritis increased with increasing ACPA levels, with a 14-fold risk depicted in subjects with anti-CCP $>250 \mathrm{U} / \mathrm{ml}$ [29]. Few of these studies, however, performed a serial analysis of anti-CCP2 titer during follow up, as was performed in our population [21,31]. In the present cohort, the percentage of patients with low or high anti-CCP2 titer was not different in the RA and non-RA groups after 2 years of observation. This reflects the substantial stability of anti-CCP2 levels over time, as has also been demonstrated in other studies [18,19,21].

One of the most interesting findings of the present study, however, is the demonstration that progression to RA in UA patients is more rapid in those with higher anti-CCP2 levels. To our knowledge, this is the first demonstration that high anti-CCP2 levels at baseline correlate with shorter time to RA diagnosis in subjects with recent onset UA. This conclusion appears to be supported by the data of a differently designed study in a cohort of healthy women, showing that detection of high anti-CCP2 levels in samples stored at baseline was strongly associated with the time to RA diagnosis, higher values being predictive of shorter time to disease onset [34].

Anti-CCP concentration does not appear to correlate with clinical disease outcomes or radiographic progression, in particular in studies analyzing serial antibody measurements over time. Neither low nor moderate to high anti-CCP titer, or relative change in antibody levels, correlated with higher risk of radiographic damage, or

Table 5 Studies evaluating the significance of anti-CCP titer in patients with undifferentiated arthritis (UA)

\begin{tabular}{|c|c|c|c|c|c|c|c|c|}
\hline $\begin{array}{l}\text { Author } \\
\text { [ref] }\end{array}$ & Patients, n & UA & $\begin{array}{l}\text { UA } \\
\text { duration }\end{array}$ & FU & Anti-CCP & $\begin{array}{c}\mathrm{CCP}+ \\
\text { baseline }\end{array}$ & UA outcome & Anti-CCP titer significance \\
\hline $\begin{array}{l}\text { Kudo- } \\
\text { Tanaka [27] }\end{array}$ & 146 & $\geq 2 \mathrm{Sj}$ & $\leq 2 \mathrm{yr}$ & $1 \mathrm{yr}$ & $\begin{array}{l}\geq 5 \mathrm{U} / \mathrm{ml} \text { no } \\
\text { serial assay }\end{array}$ & $17 \%$ & $\begin{array}{c}12 \% \text { RA } 37 \% \text { non-RA } \\
41 \% \text { UA }\end{array}$ & $\begin{array}{c}164 \pm 136 \text { RA vs } 55 \pm 72 \\
\text { non-RA/UA } P=0.017\end{array}$ \\
\hline Guzian [18] & $\begin{array}{c}253 \text { (83\% RA } \\
\text { baseline) }\end{array}$ & $\geq 3 \mathrm{Sj}$ & $\leq 1 \mathrm{yr}$ & $30 \mathrm{mo}$ & $\begin{array}{c}\geq 20 \mathrm{U} / \mathrm{ml} \\
\text { serial assay } \\
(0.30 \mathrm{mo} .)\end{array}$ & $38 \%$ & $17 \%$ RA & $\begin{array}{l}\text { No correlation low-high } \\
\text { CCP/DAS28, HAQ, erosions }\end{array}$ \\
\hline Ursum [31] & 545 & $\geq 2 \mathrm{Sj}$ & $\leq 3 \mathrm{yr}$ & $2 \mathrm{yr}$ & $\begin{array}{l}\geq 5 \mathrm{U} / \mathrm{ml} \text { serial } \\
\text { assay }(0.1 \mathrm{yr})\end{array}$ & $56 \%$ & $\begin{array}{c}\text { 63\% RA baseline or at } 1 \\
y r\end{array}$ & $\begin{array}{c}\text { No correlation CCP } \\
\text { change/DAS28, HAQ, SHS }\end{array}$ \\
\hline Emad [28] & 69 & $\geq 1 \mathrm{Sj}$ & $\leq 1 \mathrm{yr}$ & $1 \mathrm{yr}$ & $\begin{array}{c}\geq 2.9 \mathrm{U} / \mathrm{ml} \text { no } \\
\text { serial assay }\end{array}$ & $59 \%$ & $\begin{array}{l}\text { 26\% RA 6\% PsA 41\% } \\
\text { UA 26\% remission }\end{array}$ & $\begin{array}{c}\text { Correlation CCP titer/Sj, Tj, } \\
\text { ESR, erosions }\end{array}$ \\
\hline Bos $[30]$ & 147 & arthralgia & $\begin{array}{l}12(7-36) \\
\text { mo. } \\
\text { median }\end{array}$ & $\begin{array}{l}28(19-39) \\
\text { mo. } \\
\text { median }\end{array}$ & $\begin{array}{l}\geq 5 \mathrm{U} / \mathrm{ml} \text { no } \\
\text { serial assay }\end{array}$ & $34 \%$ & $\begin{array}{c}7 \% \text { RA } 13 \% \geq 4 \text { Sj } 80 \% \\
\text { no-arthritis }\end{array}$ & $\begin{array}{l}\text { Median } 141 \text { arthritis vs } 31 \\
\mathrm{U} / \mathrm{ml} \text { non-arthritis } H R=1.7\end{array}$ \\
\hline $\begin{array}{l}\text { Mjaavatten } \\
{[29]}\end{array}$ & $\begin{array}{l}376 \text { (19\% RA } \\
\text { baseline) }\end{array}$ & $\geq 1 \mathrm{Sj}$ & $\leq 16 w k$ & $1 \mathrm{yr}$ & $\begin{array}{c}\geq 25 \mathrm{U} / \mathrm{ml} \text { no } \\
\text { serial assay }\end{array}$ & $16 \%$ & $\begin{array}{l}\text { 46\% persistent } 54 \% \text { self- } \\
\text { limiting }\end{array}$ & $\begin{array}{c}\text { 25-100 OR 4.4 101-250 OR }= \\
9.4>250 \text { OR }=14 \text { for } \\
\text { persistence }\end{array}$ \\
\hline Burr [21] & $\begin{array}{l}640 \text { (49\% RA } \\
\text { baseline) }\end{array}$ & $\geq 2 \mathrm{Sj}$ & $\geq 4 w k$ & $5 \mathrm{yr}$ & $\begin{array}{l}\geq 5 \mathrm{U} / \mathrm{ml} \text { serial } \\
\text { assay }(0.5 \mathrm{yr})\end{array}$ & $30 \%$ & $72 \%$ RA $28 \%$ non-RA & $\begin{array}{c}\text { Median } 1.6 \mathrm{U} / \mathrm{ml} \text { RA vs } 0.8 \\
\mathrm{U} / \mathrm{ml} \text { non-RA }\end{array}$ \\
\hline $\begin{array}{l}\text { Present } \\
\text { study }\end{array}$ & 192 & $\geq 1 \mathrm{Sj}$ & $\leq 12 w k$ & $2 \mathrm{yr}$ & $\begin{array}{c}\text { serial assay } \\
(0.6,12,18,24 \\
\text { mo. })\end{array}$ & $42 \%$ & $\begin{array}{c}37 \% \text { RA } 30 \% \text { UA } 17 \% \\
\text { self-limiting 16\% non- } \\
\text { RA RD }\end{array}$ & $\begin{array}{l}\text { Correlation titer/time to RA } \\
\text { onset and RA development }\end{array}$ \\
\hline
\end{tabular}

RA, rheumatoid arthritis; FU, follow up; Sj, swollen joint; CCP, cyclic citrullinated peptide; $\mathrm{Tj}$, tender joint; DAS28, disease activity score; HAQ, health assessment questionnaire; PsA: psoriatic arthritis; RD, rheumatic disease; SHS, Sharp Heijde Score; ESR, erythrocyte sedimentation rate; HR, hazard ratio; OR, odds ratio. 
with outcome measures of disease activity and severity $[18,31]$. However, in a recent prospective study with a follow up of 5 years, anti-CCP concentration more than four times the upper normal limit was associated with a ten-fold increased risk of erosive disease [21]. The longer follow up characterizing this study may explain these conflicting data.

\section{Conclusions}

The results of the present study further support the value of testing anti-CCP antibodies in subjects presenting with UA. In particular, they confirmed that recent onset UA patients displaying anti-CCP antibodies have a significantly increased risk of developing RA rather than non-RA inflammatory/autoimmune diseases at 2 years. This is confirmed not only in patients with high, but also those with low antibody titer. However, initial anti-CCP levels appear to be of great importance in predicting the interval time to disease onset, since a delay in RA diagnosis could occur in subjects with low antibody levels at symptom onset. This suggests the need of closer follow up of these UA patients. Further studies, however, are needed to evaluate the influence of a peculiar genetic background on antibody level and to explore therapeutic interventions that can be directed toward specific patient subgroups considered to have the highest risks.

\begin{abstract}
Abbreviations
ACPA: anti-citrullinated peptide antibodies; ACR: American College of Rheumatology; CCP2: cyclic citrullinated peptide 2; Coxibs: Cox-2 selective inhibitors; CRP: C-reactive protein; CS: corticosteroids; DMARDs: disease modifying anti-rheumatic drugs; ESR: erythrocyte sedimentation rate; EULAR: European League Against Rheumatism; FIRMA: Forum Interdisciplinare per la Ricerca nelle Malattie Autoimmuni; HLA: human leukocyte antigen; HR: hazard ratio; NSAIDs: non-steroidal anti-inflammatory drugs; RA: rheumatoid arthritis; RF: rheumatoid factor; SE: shared epitope; UA: undifferentiated arthritis.
\end{abstract}

\section{Authors' contributions}

NB conceived the study, designed the study, designed the data collection tools, organized the collaboration, monitored data collection, drafted and revised the manuscript. EB and RG designed the study, drafted and revised the manuscript. GM and SM conceived the study, designed the study, organized the collaboration, contributed to data collection and revised the manuscript. GS and VR contributed to study design, organized the collaboration, contributed to interpretation of findings, preparation and revision of the manuscript. PS, MF, MT, AAf., OB, AAl., and CA contributed to data collection and revised the manuscript. VB performed statistical analysis, drafted and revised the manuscript. All authors have read and approved the final manuscript for publication.

\section{Competing interests}

The authors declare that they have no competing interests.

\section{Author details}

'Laboratorio di Patologia Clinica, Ospedale San Antonio, 33028 Tolmezzo, Italy. ${ }^{2}$ Struttura di Reumatologia, Dipartimento di Medicina Clinica e Sperimentale, Università di Perugia, 06122 Perugia, Italy. ${ }^{3}$ Dipartimento di Scienze Mediche, Chirurgiche e Neuroscienze, Università degli Studi di Siena, 53100 Siena, Italy. ${ }^{4}$ Dip. di Medicina Interna e Specialità Mediche, Università Sapienza di Roma, 00185 Roma, Italy. ${ }^{5}$ UOC di Patologia Clinica, D.E.A. II Umberto I, 84014 Nocera Inferiore, Italy. ${ }^{6}$ Divisione di Reumatologia, Spedali
Civili di Brescia, 25125 Brescia, Italy. 'aboratorio di Patologia Clinica, Azienda Ospedaliera Universitaria, Policlinico di Bari, 70124 Bari, Italy. ${ }^{8}$ U.O.C. di Medicina Clinica e Reumatologia, Università Campus Bio-Medico, 00128 Roma, Italy. ${ }^{9}$ U.O.C. di Reumatologia, Azienda Ospedaliera San Camillo Forlanini, 00151 Roma, Italy. ${ }^{10}$ S.C. Analisi Chimico Cliniche, Fondazione IRCCS Policlinico S.Matteo, 27100 Pavia, Italy. ${ }^{11}$ Dipartimento di Medicina Interna, Università di Perugia, 06122 Perugia, Italy.

Received: 15 October 2012 Revised: 13 December 2012

Accepted: 2 January 2013 Published: 22 January 2013

\section{References}

1. Van Venrooij W, van Beers J, Pruijn G: Anti-CCP antibodies: the past, the present and the future. Nat Rev Rheumatol 2011, 7:391-398.

2. Nishimura K, Sugiyama D, Kogata Y, Tsuji G, Nakazawa T, Kawano S, Saigo K, Morinobu A, Koshiba M, Kuntz KM, Kamae I, Kumagai S: Meta-analysis: Diagnostic accuracy of anti-cyclic citrullinated peptide antibody and rheumatoid factor for rheumatoid arthritis. Ann Intern Med 2007, 147:797-808.

3. Bizzaro N, Tonutti E, Tozzoli R, Villalta D: Analytical and diagnostic characteristics of 11 2nd- and 3rd-generation immunoenzymatic methods for the detection of antibodies to citrullinated proteins. Clin Chem 2007, 53:1527-1533.

4. van der Helm-van Mil AH, Verpoort KN, Breedveld FC, Huizinga TW, Toes RE, de Vries RR: The HLA-DRB1 shared epitope alleles are primarily a risk factor for anti-cyclic citrullinated peptide antibodies and are not and independent risk factor for development of rheumatoid arthritis. Arthritis Rheum 2006, 54:1117-1121.

5. Bartoloni E, Alunno A, Bistoni O, Bizzaro N, Migliorini P, Morozzi G, Doria A, Mathieu A, Lotzniker M, Allegri F, Riccieri V, Alpini C, Gabrielli A, Tampoia M, Gerli R, on behalf of the Forum Interdisciplinare per la Ricerca nelle Malattie Autoimmuni (FIRMA) investigators: Diagnostic value of anti-mutated citrullinated vimentin in comparison to anti-cyclic citrullinated peptide and anti-viral citrullinated peptide 2 antibodies in rheumatoid arthritis: An Italian multicentric study and review of the literature. Autoimmun Rev 2012, 11:815-820.

6. Taylor P, Gartemann J, Hsieh J, Creeden J: A systematic review of serum biomarkers anti-cyclic citrullinated peptide and rheumatoid factors tests for rheumatoid arthritis. Autoimmun Dis 2011, 2011:815038.

7. Bukhari M, Thomson W, Naseem H, Bunn D, Silman A, Symmons D, Barton A: The performance of anti-cyclic citrullinated peptide antibodies in predicting the severity of radiologic damage in inflammatory polyarthritis. Results from the Norfolk Arthritis Register. Arthritis Rheum 2007, 56:2929-2935.

8. Rönnelid J, Wick MC, Lampa J, Lindblad S, Nordmark B, Klareskog L, van Vollenhoven RF: Longitudinal analysis of citrullinated protein/peptide antibodies (anti-CP) during 5 year follow up in early rheumatoid arthritis: anti-CP status predicts worse disease activity and greater radiological progression. Ann Rheum Dis 2005, 64:1744-1749.

9. Gerli R, Bartoloni Bocci E, Sherer Y, Vaudo G, Moscatelli S, Shoenfeld Y: Association of anti-cyclic citrullinated peptide antibodies with subclinical atherosclerosis in patients with rheumatoid arthritis. Ann Rheum Dis 2008, 67:724-725.

10. Rantapää-Dahlqvist S, de Jong BAW, Berglin E, Hallmans G, Wadell G, Stenlund $H$, Sundin $U$, van Venrooij WJ: Antibodies against cyclic citrullinated peptide and IgA rheumatoid factor predict the development of rheumatoid arthritis. Arthritis Rheum 2003, 48:2741-2749.

11. Nielen MM, van Schaardenburg D, Reesink HW, van de Stadt RJ, van der Horst-Bruinsma IE, de Koning MH, Habibuw MR, Vandenbroucke JP, Dijkmans BA: Specific autoantibodies precede the symptoms of rheumatoid arthritis: a study of serial measurements in blood donors. Arthritis Rheum 2004, 50:380-386.

12. Aletaha D, Neogi T, Silman AJ, Funovits J, Felson DT, Bingham CO, Birnbaum NS, Burmester GR, Bykerk VP, Cohen MD, Combe B, Costenbader KH, Dougados M, Emery P, Ferraccioli G, Hazes JM, Hobbs K, Huizinga TW, Kavanaugh A, Kay J, Kvien TK, Laing T, Mease P, Ménard HA, Moreland LW, Naden RL, Pincus T, Smolen JS, StanislawskaBiernat E, Symmons D, et al: 2010 Rheumatoid Arthritis Classification Criteria. An American College of Rheumatology/European League Against Rheumatism Collaborative Initiative. Arthritis Rheum 2010, 62:2569-2581. 
13. van Gaalen F, Linn-Rasker S, van Venrooij W, de Jong BA, Breedveld FC, Verweij $\mathrm{CL}$, Toes RE, Huizinga TW: Autoantibodies to cyclic citrullinated peptide predict progression to rheumatoid arthritis in patients with undifferentiated arthritis. Arthritis Rheum 2004, 50:709-715.

14. Van der Linden $M$, ven der Woude D, loan-Facsinay A, Levarht EW, StoekenRijsbergen G, Huizinga TW, Toes RE, van der Helm-van Mil AH: Value of anti-modified citrullinated vimentin and third-generation anti-cyclic citrullanted peptide compared with second generation anti-cyclic citrullinated peptid and rheumatoid factor in predicting disease outcome in undifferentiated arthritis and rheumatoid arthritis. Arthritis Rheum 2009, 60:2232-2241.

15. van Dongen H, Van Aken J, Lard L, Visser K, Ronday HK, Hulsmans HM, Speyer I, Westedt ML, Peeters AJ, Allaart CF, Toes RE, Breedveld FC, Huizinga TW: Efficacy of methotrexate treatment in patients with probable rheumatoid arthritis: a double-blind, randomized, placebocontrolled trial. Arthritis Rheum 2007, 56:1424-1432.

16. Meyer O, Nicaise-Roland P, dos Santos M, Labarre C, Dougados M, Goupille P, Cantagrel A, Sibilia J, Combe B: Serial determination of cyclic citrullinated peptide antibodies predicted five-year radiological outcomes in a prospective cohort of patients with early rheumatoid arthritis. Arthritis Res Ther 2006, 8:R40.

17. Papadopoulos N, Tsiaousis G, Pavlitou-Tsiontsi A, Giannakou A, Galanopoulou V: Does the presence of anti-CCP autoantibodies and titer serum levels influence the severity and activity in rheumatoid arthritis patients? Clinic Rev Allerg Immunol 2008, 34:11-15.

18. Guzian MC, Carrier N, Cossette P, de Brum-Fernandes AJ, Liang P, Ménard HA, Boire G: Outcomes in recent-onset inflammatory polyarthritis differ according to initial titers, persistence over time and specificity of the autoantibodies. Arthritis Care Res 2010, 62:1624-1632.

19. Mjaavatten MD, van der Heijde D, Uhling T, Haugen AJ, Nygaard H, Bjørneboe O, Kvien TK: Should anti-citrullinated protein antibody and rheumatoid factor status be reassessed during the first year of follow-up in recent-onset arthritis? A longitudinal study. J Rheumatol 2011, 38:2336-2341.

20. Barra L, Pope J, Bessette L, Haraoui B, Bykerk V: Lack of seroconversion of rheumatoid factor and anti-cyclic citrullinated peptide in patients with early inflammatory arthritis: a systematic literature review. Rheumatology 2011, 50:311-316.

21. Burr M, Viatte S, Bukhari M, Plant D, Symmons DP, Thomson W, Barton A: Long-term stability of anti-cyclic citrullinated peptide antibody status in patients with early inflammatory polyarthritis. Arthritis Res Ther 2012, 14: R109.

22. Palazzi C, Buskila D, D'Angelo S, D'Amico E, Olivieri I: Autoantibodies in patients with chronic hepatitis $C$ virus infection: pitfalls for the diagnosis of rheumatic diseases. Autoimmun Rev 2012, 11:659-663.

23. Machold KP, Stamm TA, Nell VP, Pflugbeil S, Aletaha D, Steiner G, Uffmann M, Smolen JS: Very recent onset rheumatoid arthritis: clinical and serological patient characteristics associated with radiographic progression over the first years of disease. Rheumatology 2007, 46:342-349.

24. Jansen $L M$, van Schaardenburg $D$, van $d H-B$, van der Stadt RJ, de Koning MH, Dijkmans BA: The predictive value of anti-cyclic citrullinated peptide antibodies in early arthritis. J Rheumatol 2003, 30:1691-1695.

25. Kroot EJ, de Jong BA, van Leeuwen MA, Swinkels $H$, van den Hoogen FH, van't Hof M, van de Putte LB, van Rijswijk MH, van Venrooij WJ, van Riel PL: The prognostic value of anti-cyclic citrullinated peptide antibody in patients with recent-onset rheumatoid arthritis. Arthritis Rheum 2000, 43:1831-1835.

26. Kakumanu P, Sobel ES, Narain S, Li Y, Akaogi J, Yamasaki Y, Segal MS, Hahn PC, Chan EK, Reeves WH, Satoh M: Citrulline dependence of anticyclic citrullinated peptide antibodies in systemic lupus erythematosus as a marker of deforming/erosive arthritis. J Rheumatol 2009, 36:2682-2690.

27. Kudo-Tanaka F, Ohshima S, Ishii M, Mima T, Matsushita M, Azuma N, Harada Y, Katada Y, Ikeue H, Umeshita-Sasai M, Miyatake K, Saeki Y: Autoantibodies to cyclic citrullinated peptide 2 (CCP2) are superior to other potential diagnostic biomarkers for predicting rheumatoid arthritis in early undifferentiated arthritis. Clin Rheumatol 2007, 26:1627-1633.

28. Emad Y, Shehata M, Ragab Y, Saad A, Hamza H, Abou-Zeid A: Prevalence and predictive value of anti-cyclic citrullinated protein antibodies for future development of rheumatoid arthritis in early undifferentiated arthritis. Mod Rheumatol 2010, 20:358-365.

29. Mjaavatten MD, van der Heijde D, Uhlig T, Haugen AJ, Nygaard $H$, Sidenvall G, Helgetveit K, Kvien TK: The likelihood of persistent arthritis increases with the level of anti-citrullinated peptide antibody and immunoglobulin M rheumatoid factor: a longitudinal study of 376 patients with very early undifferentiated arthritis. Arthritis Res Ther 2010, 12:R76.

30. Bos WH, Wolbink GJ, Boers M, Tijhuis GJ, de Vries N, van der HorstBruinsma IE, Tak PP, van de Stadt RJ, van der Laken CJ, Dijkmans BA, van Schaardenburg D: Arthritis development in arthralgia patients is strongly associated with anti-citrullinated protein antibody status: a prospective cohort study. Ann Rheum Dis 2010, 69:490-494.

31. Ursum J, Bos WH, van Dillen N, Dijkmans BAC, van Schaardenburg D: Levels of anti-citrullinated protein antibodies and IgM rheumatoid factor are not associated with outcome in early arthritis patients: a cohort study. Arthritis Res Ther 2010, 12:R8.

32. Bos WH, Ursum J, de Vries N, Bartelds GM, Wolbink GJ, Nurmohamed MT, van der Horst-Bruinsma IE, van de Stadt RJ, Crusius JB, Tak PP, Dijkmans BA, van Schaardenburg D: The role of the shared epitope in arthralgia with anticyclic citrullinated peptide antibodies (anti-CCP) and its effect on anti-CCP levels. Ann Rheum Dis 2008, 67:1347-1350.

33. van der Woude D, Rantapää-Dahlqvist S, loan-Facsinay A, Onnekink C, Schwarte CM, Verpoort KN, Drijfhout JW, Huizinga TW, Toes RE, Pruijn GJ: Epitope spreading of the anti-citrullinated protein antibody response occurs before disease onset and is associated with the disease course of early arthritis. Ann Rheum Dis 2010, 69:1554-1561.

34. Chibnik LB, Mandl LA, Costenbader KH, Schur PH, Karlson EW: Comparison of threshold cutpoints and continuous measures of anti-cyclic citrullinated pepide antibodies in predicting future rheumatoid arthritis. J Rheumatol 2009, 36:706-711.

\section{doi:10.1186/ar4148}

Cite this article as: Bizzaro et al:: Anti-cyclic citrullinated peptide antibody titer predicts time to rheumatoid arthritis onset in patients with undifferentiated arthritis: results from a 2-year prospective study. Arthritis Research \& Therapy 2013 15:R16.

\section{Submit your next manuscript to BioMed Central and take full advantage of:}

- Convenient online submission

- Thorough peer review

- No space constraints or color figure charges

- Immediate publication on acceptance

- Inclusion in PubMed, CAS, Scopus and Google Scholar

- Research which is freely available for redistribution

Submit your manuscript at www.biomedcentral.com/submit
Ciomed Central 